\title{
The Use of Intralesional Steroids in a Case of Localized Pemphigus Foliaceus
}

\author{
Sara Ghoneim ${ }^{a}$ Martin Zaiac ${ }^{b}$ \\ ${ }^{a}$ Saba University School of Medicine, The Bottom, Netherlands Antilles; ${ }^{b}$ Department of \\ Dermatology, Herbert Wertheim College of Medicine, Florida International University, \\ Greater Miami Skin and Laser Center, Miami, FL, USA
}

\section{Keywords}

Localized pemphigus foliaceus · Intralesional injection · Topical corticosteroids

\begin{abstract}
A 37-year-old South-Asian male presented to our clinic with a crusty, verrucous-like, scaly plaque of the left ala of the nose. After ruling out infectious and other epidermal bullous diseases, we finalized a diagnosis of localized pemphigus foliaceus, an exceptionally rare disorder with only 15 cases reported in the literature to date. The hyperkeratotic lesions responded favorably to a 3-week regimen of triamcinolone ointment and a onetime intralesional triamcinolone $2.5 \mathrm{mg} / \mathrm{mL}$ injection.

(C) 2017 The Author(s)

Published by S. Karger AG, Basel
\end{abstract}

\section{Introduction}

Pemphigus foliaceus (PF), a chronic, autoimmune skin disorder, typically presents as a diffuse generalized disease characterized by blistering, scaly, and crusted erosions [1]. Epidermal accumulation of pathological IgG is common, primarily against the autoantigen desmoglein-1 [2], concomitant with $\mathrm{T}_{\mathrm{reg}^{-}}, \mathrm{T}_{\mathrm{h}^{-}}$, and B-lymphocyte infiltration and elevation of the inflammatory cytokines IL-2, IL-6, TNF- $\alpha$, and IFN- $\gamma$ [3]. PF has been associated with other autoimmune disorders, including type I diabetes, psoriasis, and myasthenia gravis [1]. 
However, genetic predisposition may be necessary but not sufficient for the etiology of PF, and the gene-environment interactions that lead to tolerance breakdown, and the resulting production of autoantibodies, remain largely unknown [3]. Autoantibody disruption of extracellular desmoglein results in flaccid bullae, and loss of keratinocyte cell-cell adhesion (acantholysis), in the superficial epidermis [3].

While the prevalence of systemic PF is high in specific geographical regions (including South America and Northern Africa), localized disease is exceptionally rare, with only 15 cases reported in the literature [4].

\section{Case Report}

A 37-year-old South-Asian male arrived at our clinic, presenting with a $1.0 \times 1.5$-cm verrucous-like encrusted plaque on an erythematous base, localized to the left nasal ala (Fig. 1). The lesion was present for more than 3 years and did not respond to topical emollients and antiseptic agents. There were no similar lesions elsewhere including the oral mucosa. He was otherwise healthy with no significant past medical history. He denied symptoms of pruritus, recent travel, or sick contacts. Differential diagnosis included seborrheic dermatitis, discoid lupus erythematosus, rosacea, lupus vulgaris, and impetigo contagiosa. A punch biopsy showed intergranular acantholysis and intradermal lymphocytic infiltration (Fig. 2a, b). Direct immunofluorescence revealed the presence of intercellular anti-desmoglein antibodies (IgG) and complement component-3 (C3) throughout the epidermis (Fig. 2c). Fungal and bacterial cultures as well as laboratory tests for anti-nuclear antibody, anti-double-stranded DNA antibodies, anti-smith, anti-Ro, and anti-La, and anti-histone proteins were negative, further supporting the diagnosis of localized PF, an exceptionally rare epidermal disorder. Initially, the hyperkeratotic lesion failed to improve with a 4-week administration of topical clobetasol propionate ointment. However, the lesion responded favorably to a treatment of triamcinolone ointment and a onetime intralesional injection of triamcinolone $2.5 \mathrm{mg} / \mathrm{mL}$. Significant improvements were noted after 3 weeks with this regimen (Fig. 3).

\section{Discussion}

Pemphigus is a family of three major life-threatening diseases, pemphigus vulgaris, PF, and paraneoplastic pemphigus [4]. PF in particular is characterized by autoantibodies (primarily IgG4) against extracellular domains (ECs) 1 and 2 of desmoglein-1, a member of the cadherin superfamily of cell adhesion proteins [1] that attaches to the keratinocyte cytoskeleton, disrupting desmosome function and leading to acantholysis [2]. Interestingly, however, patients in remission demonstrate autoimmune activity primarily to the desmoglein-1 extracellular domain EC5, and reactive T-cells generally produce a Th2-like cytokine profile, IL2 , IL-4, IL-5, IL-6, but no IFN- $\alpha$ or TNF- $\gamma$. Endemic PF (fogo selvagem) is a generalized pemphigus subtype endemic in Columbia, El Salvador, Paraguay, Peru, and Tunisia. Fogo selvagem is thought to be related to the uptake of a protein found in the saliva of a predominant black fly species (Simulium nigrimanum), and other hematophagous insect bites; the disease prevalence falls dramatically with urbanization of these regions, to a prevalence of $\sim 3.4 \%$ 
[5]. Other believed precipitating factors include medications such as angiotensin-converting enzyme inhibitors and penicillamine [1]. PF has been associated with certain neoplasms, including B-cell lymphoma, T-cell lymphoma, prostate cancer, and cutaneous squamous cell carcinoma [6]. Interestingly, our patient had no significant past medical history and no environmental triggers could be identified to possibly explain the manifestation of this autoimmune disease.

Localized PF is exceptionally rare, with only 15 cases reported in the PubMed biomedical publication library [3], with some of these individuals later developing widespread lesions via acral spreading [4]. Definitive PF diagnosis is based on three criteria: (1) the overall clinical picture, including patient history and physical exam, (2) histopathological findings of the biopsy, and (3) presence of autoantibodies. However, neither one of these criteria alone is diagnostic of PF [1]. Consequently, such cases are often mistaken for allergic contact or seborrheic dermatitis [1]. Other differential diagnoses include bullous systemic lupus erythematosus, impetigo, seborrheic dermatitis [4], papular urticaria, erythroderma, generalized exfoliative dermatitis, and subcorneal pustular dermatosis [4]. It is unclear why localized PF presents in the seborrheic distribution of the face specifically on the nose. Of the 15 cases reported in literature, 6 cases appeared on the nose with the cheeks being the second most common site (Table 1). One proposed explanation for this observation is the increased expression of PF antigen in the face and upper torso and the role of ultraviolet light in inducing the binding of anti-desmoglein-1 to the epidermis. Even with the lowest anti-desmoglein1 titers, friction or UV light may lead to blistering [1, 4]. Why some individuals have localized lesions and other have more diffuse disease is not entirely known. A genetic base appears to associate strongly with variant alleles of the genes $H L A-D R B 1{ }^{*} 0102,{ }^{*} 0404,{ }^{*} 1402$, and *1406 [7]. In localized PF, IgG (IgG4) autoantibodies are typically found in the extracellular spaces between keratinocytes and bind normal stratified squamous epithelial basement membrane $[2,8]$.

Due to the rarity of PF, treatment options vary, and a consensus has yet to be reached regarding optimal steroid doses, the use of adjuvant immunomodulators, etc. A review of 11 randomized clinical trials of 10 distinct interventions found no difference between 60 versus $120 \mathrm{mg}$ prednisolone, while the immunomodulator mycophenolate was more effective than azathioprine [9]. Other agents/approaches with reported benefit include antibiotics (e.g., minocycline, tetracycline), nicotinamide, anti-CD20 (rituximab) immunotherapy, and plasmapheresis combined with cytostatic agents and intravenous immunoglobin [7]. In less severe cases, nonsteroidal (mestinon, nicotinamide), and/or topical steroids, such as clobetasol propionate and betamethasone dipropionate may be effective [7], while an inhibitor of the T-cell activator calcineurin, pimecrolimus cream $1 \%$ once daily for 40 days, was beneficial for one case of localized PF [10]. Our patient was treated with a onetime intralesional triamcinolone injection and a topical mid-potency steroid that resulted in resolution of the lesions within weeks.

In summary, localized PF remains an exceptionally rare entity with only 15 cases reported in literature, each initially presenting on the face. The diagnosis is often challenging and requires a high degree of suspicion as clinical presentation simulates various disease entities. Early diagnosis and management may protect against disseminated disease and clinicians must have a low threshold for initiating the appropriate histo- and immunopathological studies to establish the diagnosis of this rare variant. 


\section{Statement of Ethics}

The patient gave informed consent to publish the case report.

\section{Disclosure Statement}

The authors declare that there are no conflicts of interest regarding the publication of this paper. Both authors have no financial disclosures.

\section{References}

1 James KA, Culton DA, Diaz LA: Diagnosis and clinical features of pemphigus foliaceus. Dermatol Clin 2011;29:405-412, viii.

2 Lin MS, Fu CL, Aoki V, Hans-Filho G, et al: Desmoglein-1-specific T lymphocytes from patients with endemic pemphigus foliaceus (fogo selvagem). J Clin Invest 2000;105:207-213.

-3 Aoki V, Sousa JX Jr, Diaz LA; Cooperative Group on Fogo Selvagem Research: Pathogenesis of endemic pemphigus foliaceus. Dermatol Clin 2011;29:413-418, viii.

-4 Maderal AD, Miner A, Nousari C, Alonso-Llamazares J: Localized pemphigus foliaceus with unilateral facial involvement. Actas Dermosifiliogr 2014;105:413-417.

5 Aoki V, Rivitti EA, Diaz LA; Cooperative Group on Fogo Selvagem Research: Update on fogo selvagem, an endemic form of pemphigus foliaceus. J Dermatol 2015;42:18-26.

Anhalt GJ: Paraneoplastic pemphigus. J Investig Dermatol Symp Proc 2004;9:29-33.

Culton DA, Qian Y, Li N, Rubenstein D, et al: Advances in pemphigus and its endemic pemphigus foliaceus (Fogo Selvagem) phenotype: a paradigm of human autoimmunity. J Autoimmun 2008;31:311324.

Kahana M, Trau H, Schewach-Millet M, Sofer E: Pemphigus foliaceus presenting as multiple giant seborrheic keratoses. J Am Acad Dermatol 1984;11:299-300.

-9 Martin LK, Werth VP, Villaneuva EV, Murrell DF: A systematic review of randomized controlled trials for pemphigus vulgaris and pemphigus foliaceus. J Am Acad Dermatol 2011;64:903-908. Tyros G, Kalapothakou K, Christofidou E, et al: Successful treatment of localized pemphigus foliaceus with topical pimecrolimus. Case Rep Dermatol Med 2013;2013:489618.

-11 Paramsothy Y, Lawrence CM: "Tin-tack" sign in localized pemphigus foliaceus. Br J Dermatol 1987;116:127-129.

12 Newton JA, McGibbon DH, Monk B, et al: Pemphigus foliaceus localized to the nose. Br J Dermatol 1988;118:303-312.

13 Koide M, Kokura N, Takano N: Pemphigus foliaceus localised on the face. Jpn J Dermatol 1989;97:1262. Yamamoto S, Kanekura T, Gushi A, et al: A case of localized pemphigus foliaceus. J Dermatol 1996;23:893-895.

15 Kishibe M, Kinouchi M, Ishida-Yamamoto A, et al: Pemphigus foliaceus localized to the nose. Clin Exp Dermatol 2003;28:560-562.

16 Lin R, Ladd DJ, Powell DJ, et al: Localised pemphigus foliaceus induced by topical imiquimod treatment. Arch Dermatol 2004;140:889-890.

17 Termeer CC, Technau K, Augustin M, et al: Topical tacrolimus (protopic) for the treatment of localized pemphigus foliaceus. J Eur Acad Dermatol Venereol 2004;18:636-637.

18 Zaraa I, El Euch D, Kort R, et al: Localized pemphigus: a report of three cases. Int J Dermatol 2010;49:715-716.

$>19$ Ohata C, Akamatsu K, Imai N, et al: Localized pemphigus foliaceus exclusively involving the follicular infundibulum: a novel peau d'orange appearance. Eur J Dermatol 2011;21:392-395. Walker A, Favreau T: Localized pemphigus foliaceus. Cutis 2017;99:E23-E26. 


\section{Case Reports in Dermatology}

\begin{tabular}{l|l}
\hline Case Rep Dermatol 2017;9:91-97 \\
\hline DOI: 10.1159/000477959 & $\begin{array}{l}\text { (c) } 2017 \text { The Author(s). Published by S. Karger AG, Basel } \\
\text { www.karger.com/cde }\end{array}$
\end{tabular}

Ghoneim and Zaiac: The Use of Intralesional Steroids in a Case of Localized Pemphigus Foliaceus

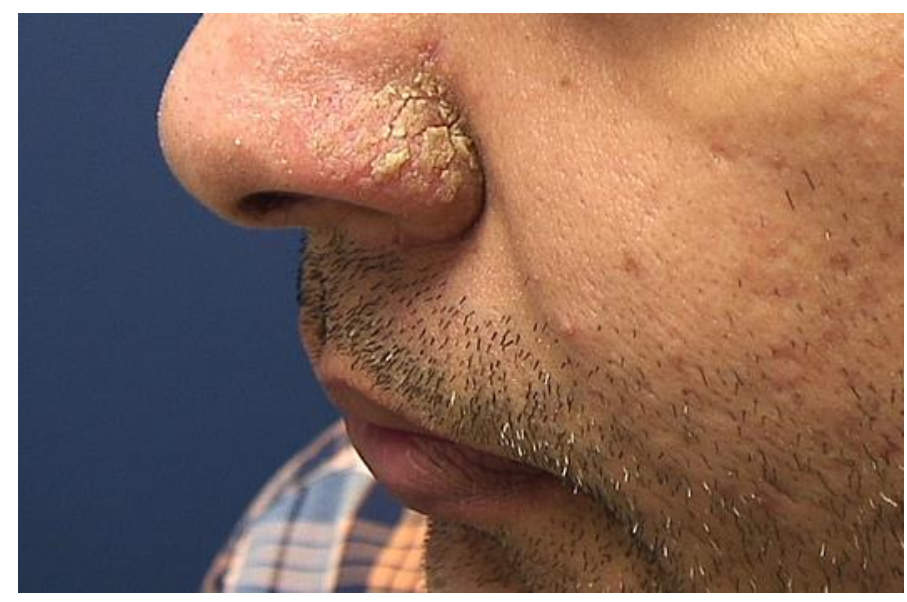

Fig. 1. $1.0 \times 1.5-\mathrm{cm}$ verrucous-like encrusted plaque and underlying erythema on the left ala.
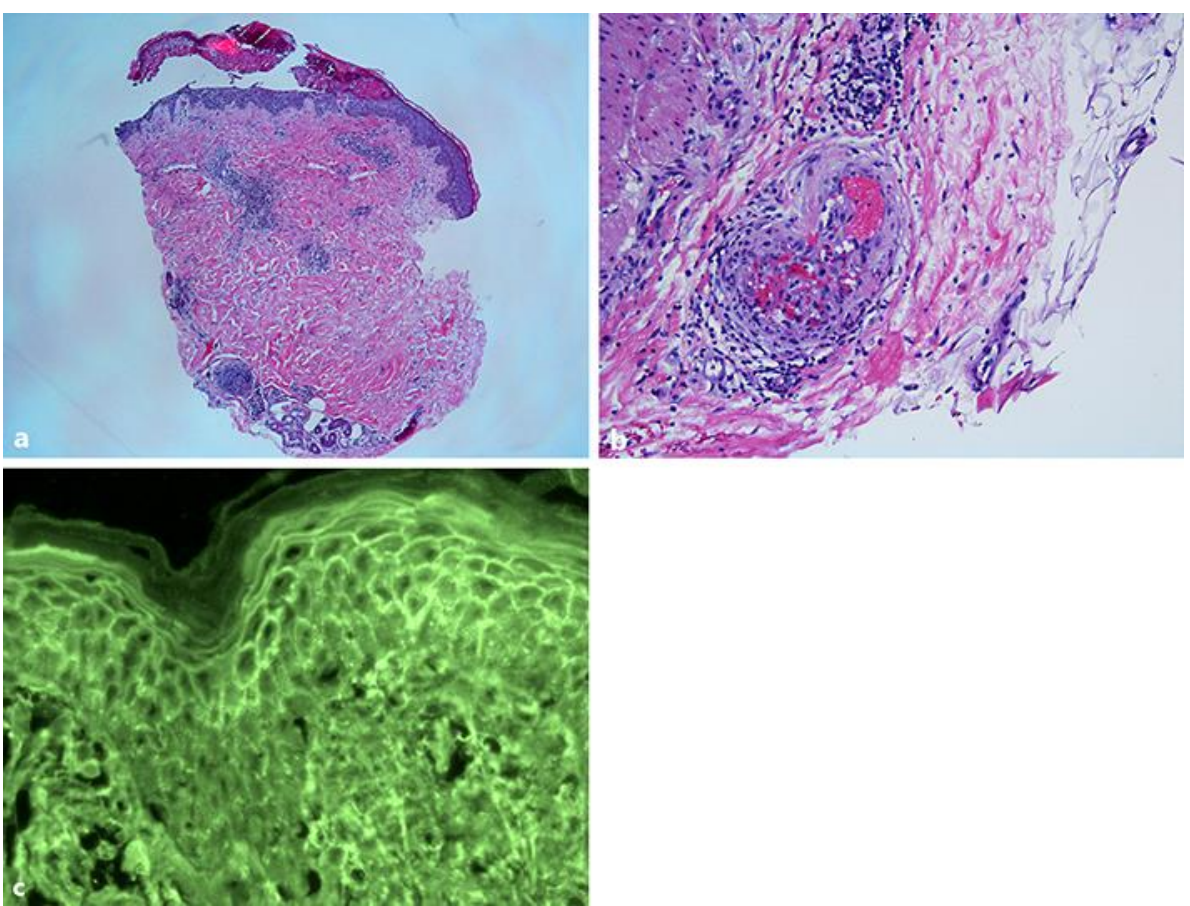

Fig. 2. a Hematoxylin and eosin stain, original magnification $\times 2$, showing intergranular acantholysis. b Hematoxylin and eosin stain, original magnification $\times 20$, showing intergranular acantholysis, superficial blistering, and dermal lymphocytic infiltration. c Direct immunofluorescence showing intercellular IgG and C3 deposits throughout the epidermis. 


\section{Case Reports in Dermatology}

www.karger.com/cde

Ghoneim and Zaiac: The Use of Intralesional Steroids in a Case of Localized Pemphigus Foliaceus

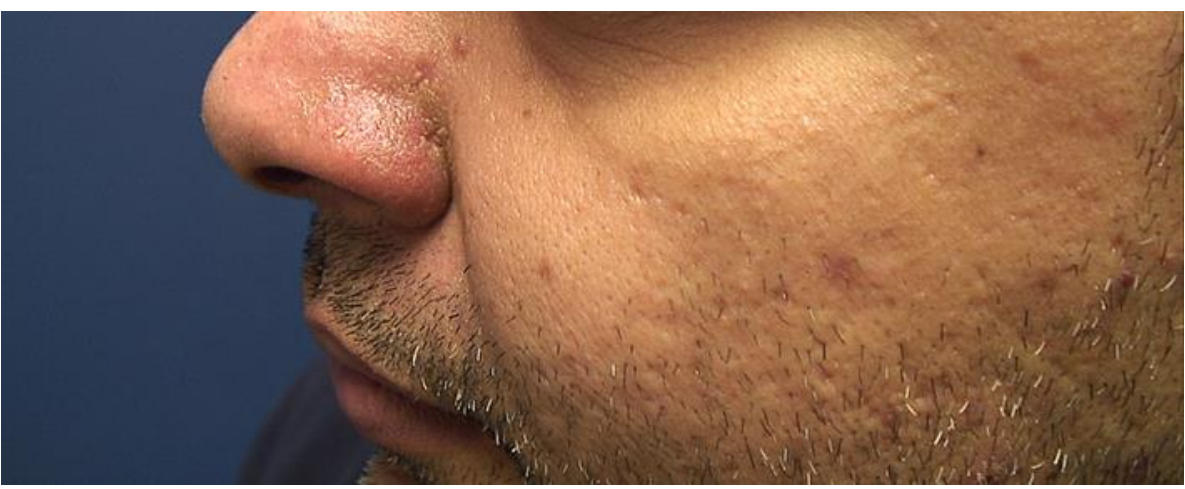

Fig. 3. The lesion after treatment with onetime intralesional injection of $2.5 \mathrm{mg} / \mathrm{mL}$ of triamcinolone and 3week topical application of triamcinolone ointment. 
Table 1. Summary of reported cases of localized pemphigus foliaceus

\begin{tabular}{|c|c|c|c|c|c|c|c|}
\hline Author, Ref., Year & Age, sex & Location & Spreada & $\mathrm{DIFb}$ & $\mathrm{IIFb}$ & ELISA $^{\mathrm{b}}$ & Therapy \\
\hline \multirow[t]{2}{*}{$\begin{array}{l}\text { Paramsothy and } \\
\text { Lawrence [11], } 1987\end{array}$} & $34, \mathrm{M}$ & nose & + & $\begin{array}{l}\text { IgG between epidermal } \\
\text { cells }\end{array}$ & positive & $\mathrm{N} / \mathrm{A}$ & oral prednisolone \\
\hline & $65, \mathrm{M}$ & nose & + & $\begin{array}{l}\text { IgG between epidermal } \\
\text { cells and IgM in basement } \\
\text { membrane }\end{array}$ & positive & $\mathrm{N} / \mathrm{A}$ & $\begin{array}{l}\text { topical clobetasol propi- } \\
\text { onate }\end{array}$ \\
\hline \multirow[t]{3}{*}{$\begin{array}{l}\text { Newton et al. [12], } \\
1988\end{array}$} & $27, \mathrm{M}$ & nose & - & intercellular IgG and C3 & & & $\begin{array}{l}\text { topical clobetasol propi- } \\
\text { onate }\end{array}$ \\
\hline & $62, \mathrm{~F}$ & nose & + & intercellular IgG & positive & $\mathrm{N} / \mathrm{A}$ & oral cyclophosphamide \\
\hline & $43, \mathrm{M}$ & nose & - & $\mathrm{N} / \mathrm{A}$ & $\mathrm{N} / \mathrm{A}$ & $\mathrm{N} / \mathrm{A}$ & oral prednisone \\
\hline $\begin{array}{l}\text { Koide et al. [13], } \\
1989\end{array}$ & $64, \mathrm{~F}$ & cheek & - & $\begin{array}{l}\text { IgG between epidermal } \\
\text { cells }\end{array}$ & $\mathrm{N} / \mathrm{A}$ & - & oral prednisone \\
\hline $\begin{array}{l}\text { Yamamoto et al. [14], } \\
1996\end{array}$ & $81, \mathrm{~F}$ & cheek & - & $\begin{array}{l}\text { IgG in intercellular space in } \\
\text { epidermis }\end{array}$ & & - & $\begin{array}{l}\text { oral minocycline, nico- } \\
\text { tinamide, topical betame- } \\
\text { thasone valerate }\end{array}$ \\
\hline $\begin{array}{l}\text { Kishibe et al. [15], } \\
2003\end{array}$ & $63, M$ & nose & - & IgG deposition & - & - & oral prednisolone \\
\hline $\begin{array}{l}\text { Lin et al. [16], } \\
2004\end{array}$ & $53, \mathrm{~F}$ & face & - & $\begin{array}{l}\text { IgG deposition in granular } \\
\text { layer }\end{array}$ & $\mathrm{N} / \mathrm{A}$ & $\mathrm{N} / \mathrm{A}$ & $\begin{array}{l}\text { i.m. } 0.1 \% \text { TAC, topical } \\
\text { clobetasol propionate, } \\
\text { and oral prednisone }\end{array}$ \\
\hline $\begin{array}{l}\text { Termeer et al. [17], } \\
2004\end{array}$ & $83, \mathrm{M}$ & scalp & - & IgG in the upper epidermis & $\mathrm{N} / \mathrm{A}$ & $\mathrm{N} / \mathrm{A}$ & $\begin{array}{l}\text { tacrolimus } 0.1 \% \text { oint- } \\
\text { ment }\end{array}$ \\
\hline \multirow[t]{2}{*}{$\begin{array}{l}\text { Zaraa et al. [18], } \\
2010\end{array}$} & $42, \mathrm{~F}$ & scalp & - & IgG in the upper epidermis & + & + & $\begin{array}{l}\text { topical clobetasol propi- } \\
\text { onate }\end{array}$ \\
\hline & $34, \mathrm{~F}$ & cheek & - & IgG in the upper epidermis & $\mathrm{N} / \mathrm{A}$ & + & $\begin{array}{l}\text { oral prednisone and } \\
\text { cyclophosphamide }\end{array}$ \\
\hline $\begin{array}{l}\text { Ohata et al. [19], } \\
2011\end{array}$ & $68, \mathrm{~F}$ & cheek & + & IgG in the upper epidermis & $\mathrm{N} / \mathrm{A}$ & + & oral prednisone \\
\hline $\begin{array}{l}\text { Maderal et al. [4], } \\
2014\end{array}$ & $19, \mathrm{~F}$ & cheek & - & $\begin{array}{l}\text { IgG in intercellular space in } \\
\text { epidermis }\end{array}$ & $\mathrm{N} / \mathrm{A}$ & - & $\begin{array}{l}\text { oral prednisone and } \\
\text { topical clobetasol propi- } \\
\text { onate }\end{array}$ \\
\hline $\begin{array}{l}\text { Walker and Favreau } \\
{[20], 2017}\end{array}$ & $51, \mathrm{~F}$ & cheek & + & $\begin{array}{l}\text { IgG in intercellular space in } \\
\text { epidermis }\end{array}$ & & + & $\begin{array}{l}\text { oral prednisone and } \\
\text { mycophenolate mofetil }\end{array}$ \\
\hline Current case & $37, \mathrm{M}$ & nose & - & $\begin{array}{l}\text { IgG between epidermal } \\
\text { cells }\end{array}$ & - & $\mathrm{N} / \mathrm{A}$ & $\begin{array}{l}\text { intralesional TAC } 2.5 \\
\mathrm{mg} / \mathrm{mL} \text { and topical TAC } \\
\text { ointment }\end{array}$ \\
\hline
\end{tabular}

M, male; F, female; DIF, direct immunofluorescence; IIF, indirect immunofluorescence; ELISA, enzyme-linked immunosorbent assay; N/A, not available; TAC, triamcinolone. ${ }^{a}+$ indicates spread of disease; - the disease did not spread. ${ }^{b}+$ indicates present; - indicates not present. 